\title{
Bioremediation of High Strength Ammonia Laden Fertilizer Industry Effluent with Extremely Low C: N Ratio Using Simultaneous Aerobic Nitrification and Denitrification
}

\author{
Radhika Priyadarshan Keluskar ${ }^{1,2} *$ \\ ${ }^{1}$ Department of Microbiology and Biotechnology Centre, The M. S. University of Baroda, \\ Vadodara - 390 002, Gujarat, India \\ ${ }^{2}$ Department of Post-Harvest Technology, ICAR-Central Institute of Fisheries Education (CIFE), \\ Andheri (W), Mumbai-400061, India \\ *Corresponding author
}

A B S T R A C T

\begin{tabular}{|l|}
\hline K e y w o r d s \\
Simultaneous nitrification \\
and denitrification, \\
Industrial effluent, \\
$\begin{array}{l}\text { Ammonia oxidizing } \\
\text { bacteria, Nitrite oxidizing } \\
\text { bacteria, Aerobic } \\
\text { denitrifiers, Wastewater } \\
\text { treatment. }\end{array}$ \\
\hline Article Info \\
\hline $\begin{array}{l}\text { Accepted: } \\
\text { 21 October } 2017 \\
\text { Available Online: } \\
10 \text { December } 2017\end{array}$ \\
\hline \hline
\end{tabular}

In the present study, autotrophic ammonia- and nitrite- oxidizing bacteria (AOB and NOB respectively) were enriched and methodically added to treat ammonia laden effluent (700 $\mathrm{ppm}$ ) of a fertilizer industry with exceedingly low $\mathrm{C}$ : $\mathrm{N}$ ratio. An open aerobic reactor system of $5.3 \mathrm{~L}$ was developed and run in the batch mode for the first 30 days to acclimatize the biomass with increasing effluent concentration. A linear correlation was observed during the batch mode between the amount of ammonia oxidized and the ammonia loading rate $\left(\mathrm{R}^{2}\right.$ 0.79). On making the system continuous, $99 \% \mathrm{NH}_{4}{ }^{+} \mathrm{N}$ removal was achieved along with complete utilization of indigenous carbon without accumulation of $\mathrm{NO}_{2}^{-}-\mathrm{N}$ and $\mathrm{NO}_{3}{ }^{-}-\mathrm{N}$. Molecular microbial analysis showed presence of AOB belonging to Nitrosomonas sp., NOB belonging to Nitrobacter sp. and aerobic denitrifiers mainly Achromobacter sp., Sphingomonas sp., Pusillimonas sp., Mesorhizobium sp. and Alcaligenes sp. coexisting in the system. Their concerted growth and simultaneous aerobic nitrification denitrification (SND) activity led to efficient removal of nutrients from the effluent and suggested high potential of the developed system in bioremediating industrial effluents with low $\mathrm{C}$ : $\mathrm{N}$ ratio.

\section{Introduction}

India is amongst the top two farm producers in the world implying that agriculture plays a vital role in India's economy (Arjun, 2013). Soil yield depends on nitrogen, phosphorous and potassium (fertilizing elements) and Indian soil which is generally deficient in these elements requires them to be given externally. Owing to the increased demand for fertilizers, a rapid growth has been observed in the fertilizer industries (Smriti Chan, Growth and Distribution of Fertilizers
Industry in India, article). These industries generally lack proper waste management systems. Untreated wastes when channeled into aquatic environment causes extensive damage to the water quality and ecology of the environment specifically when microbial degradation activities cannot cope up with the fast removal of the toxic pollutants (Obire et al., 2008). Very few bioremediation studies have been carried out for the treatment of wastewater from fertilizer industry. George $e t$ 
al., (1997) used immobilized urease enzyme to develop an efficient system that could operate at lower residence time but its application at large scale would become a costly affair. Hence, there is an urgent need to develop microbial systems that can sustain toxic compounds and can lead to rapid, cost effective remediation of the waste generated from fertilizer industries.

Recently, unusual behavior of nitrifiers and denitrifiers has been observed. Production of nitrous oxide by autotrophic ammonia oxidizing bacteria (AOB) through nitrifier denitrification had been reported by Hayatsu et al., (2008). Denitrifying enzymes are sensitive to oxygen, was a long established fact but lately Paracoccus denitrificans, Thiosphaera pantotropha, Mesorhizobium sp., Burkholderia cepacia and others are reported to denitrify under aerobic conditions (Hayatsu et al., 2008). This indicates that conversion of ammonia to molecular nitrogen can be carried out either by a single kind of bacteria or nitrification and denitrification can occur concurrently in a single reactor under identical operating conditions (Daigger and Littleton, 2000). In a study carried out by Keluskar et al., (2013), partial nitrification, anammox and denitrification was employed for the removal of ammonia from fertilizer industry under anoxic conditions. Anammox bacteria have very slow grown rate compared to heterotrophs and other autotrophic ammonia oxidizing microorganisms (Strous et al., 1999). Therefore, application of this process (though highly efficient) at large scale would be time consuming especially during the start-up phase. Very few studies have focused on the use of nitrification along with aerobic denitrification for the treatment of high strength ammonia containing wastewater (Gupta and Gupta, 2001).

The objective of the present study was to develop a microbial system for bioremediating ammonia laden effluent from a fertilizer industry through simultaneous aerobic nitrification and denitrification. The developed system contained AOB, NOB and aerobic denitrifiers which collectively removed nutrients from the effluent without accumulating nitrite and nitrate.

\section{Materials and Methods}

\section{Enrichment of autotrophic ammonia and nitrite oxidizing bacteria (AOB and $\mathrm{NOB}$ )}

Enrichment of AOB and NOB was carried out from different soil and sludge samples by inoculating 5\% sample in inorganic medium described by Hyman and Arp (1992) for AOB and for NOB, ammonium sulphate in the media was replaced with $0.1 \%$ sodium nitrite. They were incubated in a shaker incubator at $30{ }^{\circ} \mathrm{C}$ temperature for 1 month and were subcultured in the same media to examine their ammonia and nitrite oxidizing activity. Ammonia oxidizing activity was measured in terms of ammonia removed and nitrite produced and similarly for nitrite oxidizing activity, nitrite removed and nitrate formation was measured. Samples showing maximum activity were selected amongst the enriched $\mathrm{AOB}$ and NOB.

\section{Characteristics of the fertilizer industry effluent}

Fertilizer industry effluent was collected from site and brought to the experimental laboratory in a closed container and stored at $4^{\circ} \mathrm{C}$ till the end of the study. The effluent contained high ammonia concentration $\left(\mathrm{NH}_{4}{ }^{+}-\mathrm{N}: 675 \pm 38 \mathrm{mg} / \mathrm{L}\right)$, whereas $\mathrm{NO}_{2}{ }^{-} \mathrm{N}$ was around $41 \pm 1.1 \mathrm{mg} / \mathrm{L}$ and $\mathrm{NO}_{3}{ }^{-}-\mathrm{N}$ was below detectable limit. $\mathrm{pH}$ of the effluent was high ( $\mathrm{pH}$ 9.6). Biological oxygen demand (BOD), chemical oxygen demand (COD) and dissolved oxygen (DO) were $29 \mathrm{mg} / \mathrm{L}, 46.66$ $\mathrm{mg} / \mathrm{L}$ and $8 \mathrm{mg} / \mathrm{L}$ respectively. The effluent 
also contained metals like nickel (Ni) 1.16 $\mathrm{mg} / \mathrm{L}$ and iron $(\mathrm{Fe}) 0.07 \mathrm{mg} / \mathrm{L}$.

\section{SND type reactor set-up and operational conditions}

A $5.3 \mathrm{~L}$ open aerobic reactor $(16 \times 26 \times 39$ $\mathrm{cm})$ was operated continuously for the removal of ammonia from effluent of a fertilizer company. A settler tank was attached to the reactor at $45^{\circ}$ angle (Figure 1). The reactor was kept on a magnetic stirrer for agitation at $240 \mathrm{rpm}$. Dissolved oxygen (DO) in the reactor [measured by YSI DO meter (YSI200 portable DO meter, USA)] was also maintained using an external aerator. Aeration and agitation were switched on and off intermittently at $24 \mathrm{~h}$ interval. Enriched seed biomass was added such that the MLVSS in the reactor at the start of the run was $8.2 \mathrm{~g} / \mathrm{L}$. The reactor was run initially in the batch mode for first 30 days and was then made continuous with a flow rate of $32.7 \mathrm{ml} / \mathrm{h}$ for the next 45 days. Levels of ammonia, nitrite, nitrate, $\mathrm{pH}, \mathrm{DO}$, mixed liquor volatile suspended solids (MLVSS), mixed liquor suspended solids (MLSS), sludge volume index (SVI) were measured as per the methods described in APHA standard methods (APHA, 2005). Chemical oxygen demand (COD) was measured according to IS 3025 (Part 58): (2006). Ammonia conversion efficiency was calculated according to Daverey et al., (2012).

\section{Evaluation of the microbial biomass developed in the reactor}

Microorganisms present in the reactor were identified by $16 \mathrm{~S}$ rRNA gene amplification, cloning and sequencing. Sludge $(1 \mathrm{ml})$ was taken from the settler tank and centrifuged at $19,200 \mathrm{X} \mathrm{g}$ for $15 \mathrm{~min}$. DNA was extracted according to Schmidt et al., (1991). 16S rRNA gene was amplified using universal primer 27F 5' AGAGTTTGATCCTGGCT
CAG 3' and 1541R 5' AAGGAGGTGATC CAGCCGCA 3' according to Keluskar et al., (2013) and cloned in pTZ57R/T vector, using INSTA cloning kit (Fermentas). From the 16S rRNA gene clone library, 50 clones were randomly selected and subjected to amplified ribosomal DNA restriction analysis (ARDRA) using $A l u \mathrm{I}$ restriction enzyme to avoid redundant sequencing.

Nine different patterns were observed through restriction analysis and representative $16 \mathrm{~S}$ rRNA gene of the 9 different patterns (data not shown) was sequenced commercially by Single Pass Analysis (Bangalore Genei, India). The sequences determined in the study were submitted in GenBank (accession numbers KY704099 to KY704107). Blast analysis of the obtained sequences was carried out to know the identity of the microorganisms.

\section{Results and Discussion}

\section{Development of seed consortium}

AOB and NOB were enriched individually from different soil and sludge samples. Amongst the enriched $\mathrm{AOB}$ and $\mathrm{NOB}, \mathrm{PF}$ (paddy field soil sample) showed maximum ammonia oxidizing activity $(216 \pm 0.3 \mathrm{mg} / \mathrm{L}$ $\mathrm{NH}_{4}{ }^{+}-\mathrm{N}$ removed and $103.68 \pm 0.18 \mathrm{mg} / \mathrm{L}$ $\mathrm{NO}_{2}{ }^{-} \mathrm{N}$ produced) as well as nitrite oxidizing activity $\left(1.094 \pm 0.22 \mathrm{mg} / \mathrm{ml} \mathrm{NO}_{2}{ }^{-}-\mathrm{N}\right.$ removed and $0.67 \pm 0.054 \mathrm{mg} / \mathrm{ml} \mathrm{NO}_{3}{ }^{-}-\mathrm{N}$ formed) in their respective media and were therefore selected for further studies (Table 1). A longer lag period was observed in the nitrite oxidizing activity of PF-NOB whereas PFAOB showed increase in ammonia oxidizing activity almost parallel to its growth (Figure $2 \mathrm{~A}$ and $\mathrm{B}$ respectively). Specific growth rate constants for the PF-NOB and PF-AOB enriched biomass were 0.384 and 1.24 with doubling time of 1.8 and 0.56 days respectively. A seed consortium was prepared 
for inoculating the aerobic reactor by mixing $\mathrm{AOB}$ and NOB in the ratio 1:4.

\section{Removal of ammonia from fertilizer industry effluent}

A 5.3 $\mathrm{L}$ open aerobic reactor was designed for the simultaneous growth of AOB and NOB. The reactor was run in the batch mode for first 30 days with increasing $\mathrm{NH}_{4}{ }^{+}-\mathrm{N}$ load. Four dilutions (1:5, 1:3, 1:1 and 1:0.5) of the effluent were used to increase $\mathrm{NH}_{4}{ }^{+}-\mathrm{N}$ load in the influent (Figure 3A). Around 90\% $\mathrm{NH}_{4}{ }^{+}$$\mathrm{N}$ removal was achieved without significant build-up of $\mathrm{NO}_{2}^{-}-\mathrm{N}$ and $\mathrm{NO}_{3}^{-}-\mathrm{N}$ along with $82.68 \mathrm{mg} / \mathrm{L}$ biomass accumulation by the end of the run in the batch mode (Figure 3A, B and $\mathrm{C})$. A linear correlation $\left(\mathrm{R}^{2} 0.799\right)$ existed between the ammonia load and the amount of ammonia removed in the system (Figure 4A).

During the start of the continuous mode, some amount of biomass was washed away and the MLVSS value dropped to $31.56 \mathrm{mg} / \mathrm{L}$ which then steadily increased to around $116 \mathrm{mg} / \mathrm{L}$ by $55^{\text {th }}$ day and remained constant thereafter, with more than $90 \% \mathrm{NH}_{4}{ }^{+}-\mathrm{N}$ removal (Figure $3 \mathrm{~A}$ and $\mathrm{C}$ ). By the end of the run, 99\% reduction in the level of $\mathrm{NH}_{4}{ }^{+}-\mathrm{N}$ was observed (Figure 3A). A distinct drop in the $\mathrm{pH}$ from 8.0 to 6.8 of the system, during the batch mode, was indicative of the nitrifying activity in the reactor. Ammonia conversion efficiency was between 56.7 to $28 \%$ during this period also suggesting nitrifying activity in the system (Figure 4B). During continuous mode of operation, $\mathrm{pH}$ of the system remained between $\mathrm{pH} 7.4$ to 7.8 (Figure 3C). Level of COD of the effluent reduced from 46 $\mathrm{mg} / \mathrm{L}$ to below detectable limits ( $\mathrm{p}$-value < 0.005). Ammonia conversion efficiency was very low during the steady state $\left(56-75^{\text {th }}\right.$ day) which suggested high denitrifying activity during this period (Figure 4B). Nitrogen formed in the system could not be monitored as it was an open reactor. Dissolved oxygen concentration fluctuated between 7.6 and 7.9 $\mathrm{mg} / \mathrm{L}$ during the aeration and agitation period whereas it decreased to $5.7 \pm 0.4 \mathrm{mg} / \mathrm{L}$ in the off mode. SVI and food to mass ratio of the system were $22.4 \mathrm{ml} / \mathrm{g}$ and 0.45 respectively.

Molecular microbial analysis showed presence of nitrifying and denitrifying bacteria in the system. Amongst the identified microorganisms, two groups of $\mathrm{AOB}$ were present which had sequence identity with Nitrosomonas sp. ENI11 (99\%) and Nitrosomonas sp. DYS317 (99\%). NOB in the system belonged to Nitrobacter sp. (99\%). Presence of heterotrophic denitrifiers like Achromobacter sp., (99\%), Sphingomonas sp. (99\%), Pusillimonas sp. (99\%), Mesorhizobium sp. (99\%) and Alcaligenes sp. (99\%) was also observed in the system.

Wastewater from the fertilizer industry contained very high levels of ammonical nitrogen and negligible amounts of organic carbon owing to which nitrifying microbial community were employed for its treatment. A syntrophic association is known to exist between AOB and autotrophic nitrite oxidizing bacteria (NOB) and they can therefore coexist in biofilms or in aggregates in wastewater treatment plants (Schramm et al., 1999; Sliekers et al., 2005; Siripong and Rittmann, 2007). AOB are described to be present in the outer regions of the biofilms or aggregates and provide nitrite (nitrogen source) to NOB residing in their close vicinity in the inner portion of the biofilms or aggregates (Schramm et al., 1999). Keeping this in mind a seed consortium containing AOB and NOB was developed. As AOB and NOB enriched from PF (paddy field soil sample) showed highest nitrifying activity, they were selected for seed consortium development (Table 1). 
Table.1 Ammonia and nitrite oxidizing activity of enriched AOB and NOB measured after 1 week of incubation from varied sources

\begin{tabular}{|c|c|c|c|c|c|c|}
\hline \multirow[b]{2}{*}{$\begin{array}{l}\text { Sr. } \\
\text { No. }\end{array}$} & \multirow[b]{2}{*}{ Sample } & \multirow[b]{2}{*}{ Description } & \multicolumn{2}{|c|}{ Enrichment of AOB } & \multicolumn{2}{|c|}{ Enrichment of NOB } \\
\hline & & & $\begin{array}{c}\mathrm{NH}_{4}{ }^{+}-\mathrm{N} \\
\text { removed }(\mathrm{mg} / \mathrm{L})\end{array}$ & $\begin{array}{l}\mathrm{NO}_{2}-\mathrm{N} \text { formed } \\
(\mathrm{mg} / \mathrm{L})\end{array}$ & $\begin{array}{l}\mathrm{NO}_{2}^{-}-\mathrm{N} \\
\text { removed } \\
(\mathrm{mg} / \mathrm{ml})\end{array}$ & $\begin{array}{l}\mathrm{NO}_{3}{ }^{-}-\mathrm{N} \text { formed } \\
(\mathrm{mg} / \mathrm{ml})\end{array}$ \\
\hline 1 & N1 & $\begin{array}{l}\text { Common effluent treatment } \\
\text { plant, Nandesari }\end{array}$ & $17.1 \pm 0.25$ & $8.0 \pm 0.02$ & $1.092 \pm 0.05$ & $0.53 \pm 0.08$ \\
\hline 2 & $\mathrm{~N} 2$ & $\begin{array}{l}\text { Sludge from Nandesari (Deepak } \\
\text { nitrite) }\end{array}$ & $4.67 \pm 0.07$ & $2.9 \pm 0.04$ & $0.22 \pm 0.03$ & $0.31 \pm 0.06$ \\
\hline 3 & $\mathrm{~N} 4$ & $\begin{array}{l}\text { (Municipal waste water } \\
\text { treatment plant, Nandesari) }\end{array}$ & $186 \pm 0.091 *$ & $99.5 \pm 0.87 *$ & $0.27 \pm 0.09$ & $0.2 \pm 0.023$ \\
\hline 4 & GSFC & $\begin{array}{l}\text { Fertilizer industry sludge } \\
\text { sample, Vadodara, }\end{array}$ & $18.55 \pm 0.86$ & $12.0 \pm 0.12$ & $0.0 \pm 0.0 .02$ & $0.12 \pm 0.09$ \\
\hline 5 & DNRB & $\begin{array}{l}\text { (DNR-B reactor), Sludge } \\
\text { sample GNFC, Bharuch, }\end{array}$ & $134 \pm 0.5^{*}$ & $97.3 \pm 0.19 *$ & $1.092 \pm 0.14$ & $0.45 \pm 0.06$ \\
\hline 6 & WC & Winogradsky’s column & $10.97 \pm 0.49$ & $3.6 \pm 0.23$ & $1.092 \pm 0.54 *$ & $0.62 \pm 0.103^{*}$ \\
\hline 7 & NW & Narol, wheat bulk soil & $3.2 \pm 0.082$ & $0.11 \pm 0.05$ & $1.093 \pm 0.2$ & $0.54 \pm 0.014$ \\
\hline 8 & PF & Mandya, paddy field soil & $216 \pm 0.3 *$ & $103.68 \pm 0.18^{*}$ & $1.094 \pm 0.22 *$ & $0.67 \pm 0.054 *$ \\
\hline 9 & ECP & $\begin{array}{l}\text { Jowar soil (Effluent channel } \\
\text { project) Ahemdabad, }\end{array}$ & $5.8 \pm 0.037$ & $0.13 \pm 0.021$ & $1.093 \pm 0.9 *$ & $0.61 \pm 0.043^{*}$ \\
\hline 10 & VW & Wheat soil, Vinjal & $13.94 \pm 0.56$ & $0.12 \pm 0.003$ & $1.092 \pm 0.19$ & $0.55 \pm 0.108$ \\
\hline
\end{tabular}

Fig.1 A 5.3 L open reactor used in the study for the treatment of fertilizer industry effluent and the sludge retained in the settler

Reactor

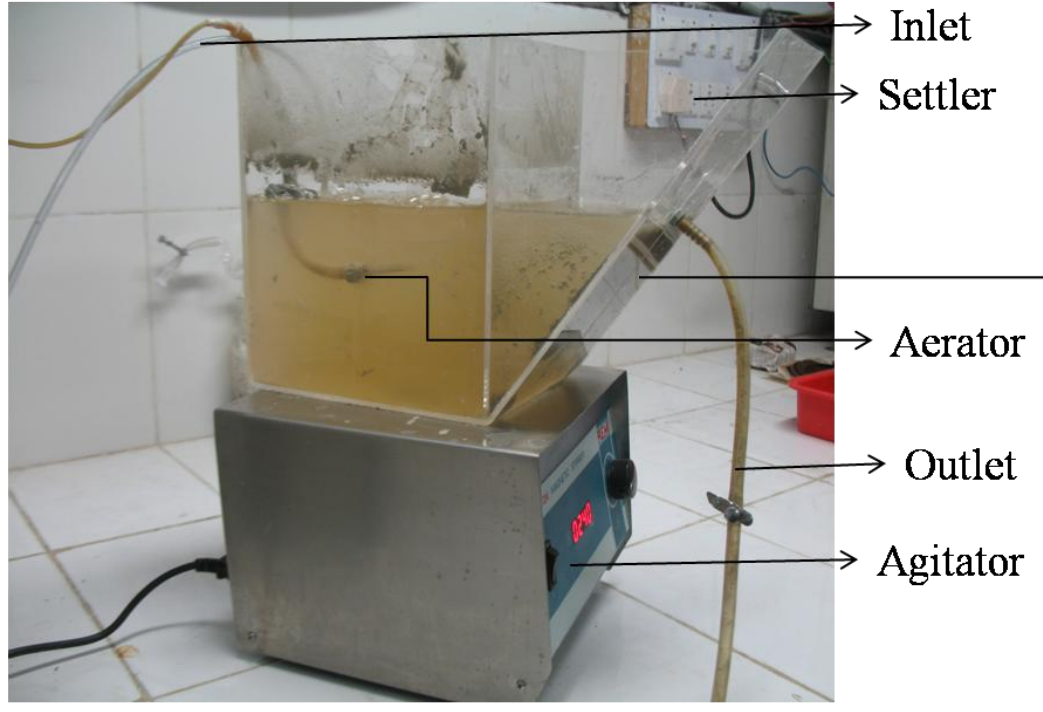

Sludge settled in the reactor settler 
Fig.2 Growth and nitrifying activity of enriched biomass A) PF-NOB B) PF-AOB
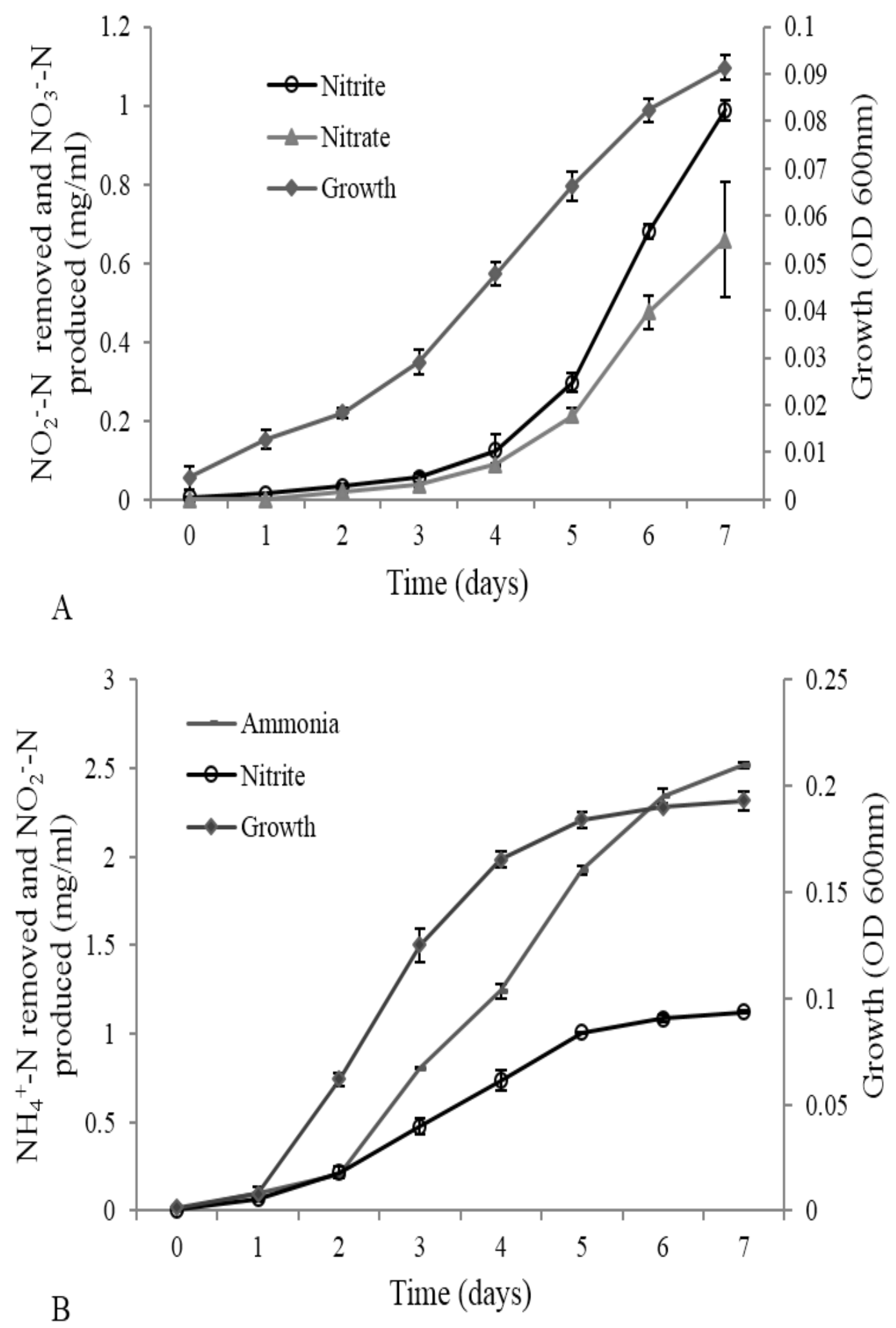
Fig.3 Nitrogen removal performance by the SND type reactor. Change in the levels of A) $\mathrm{NH}_{4}{ }^{+}$ $\mathrm{N}$ and Ammonia removing efficiency B) $\mathrm{NO}_{2}{ }^{-}-\mathrm{N}$ and $\mathrm{NO}_{3}{ }^{-}-\mathrm{N} \mathrm{C}$ ) $\mathrm{pH}$ and MLVSS. Values mentioned in the box are the ratio of effluent dilution with inorganic media without nitrite or ammonia
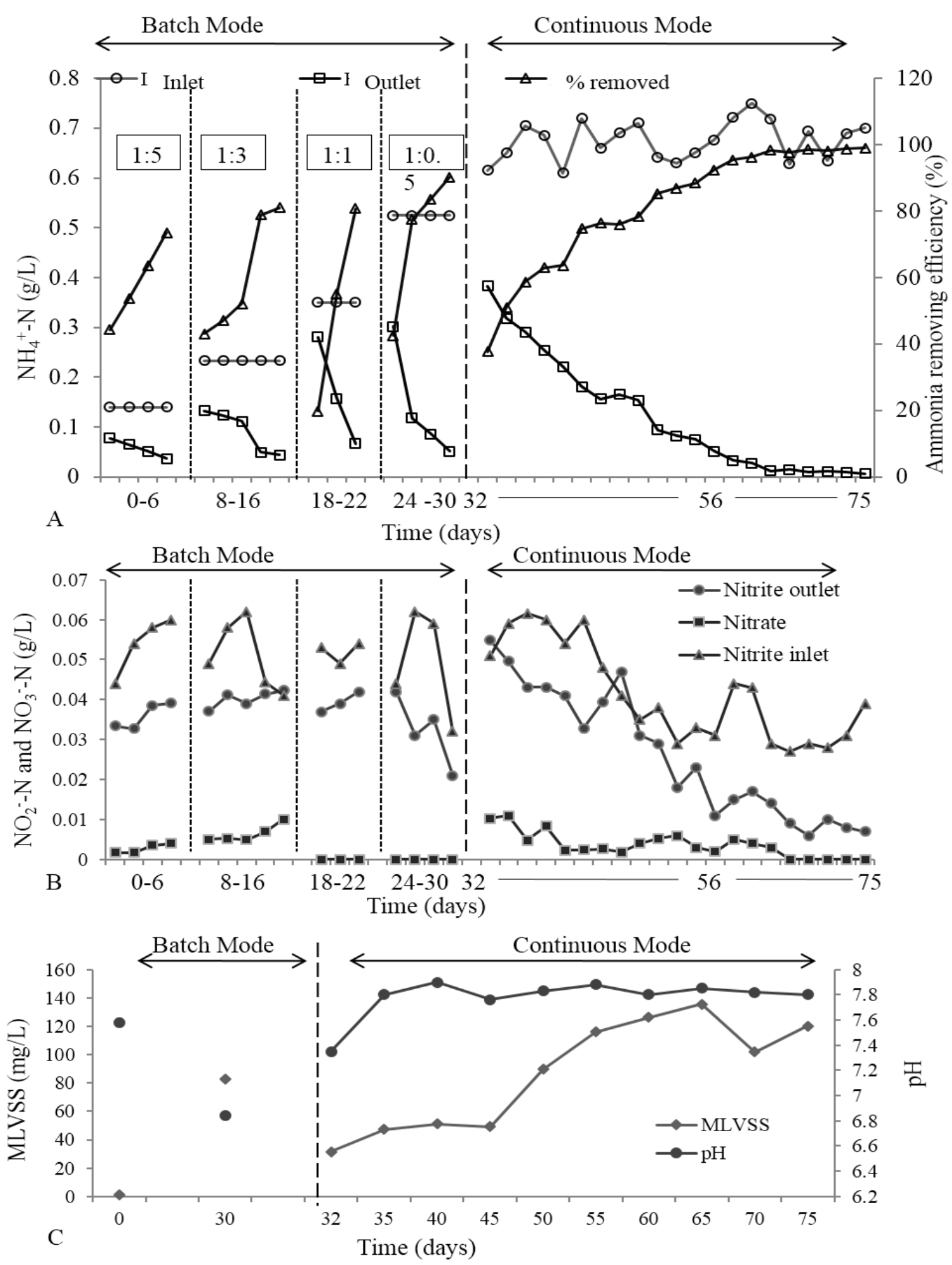
Fig.4 Stability and efficiency of the system A) Correlation between the concentration of ammonia oxidized ( $\mathrm{g} / \mathrm{L}$ ) to the applied ammonia load ( $\mathrm{g} / \mathrm{L} /$ day). B) Ammonia conversion efficiency
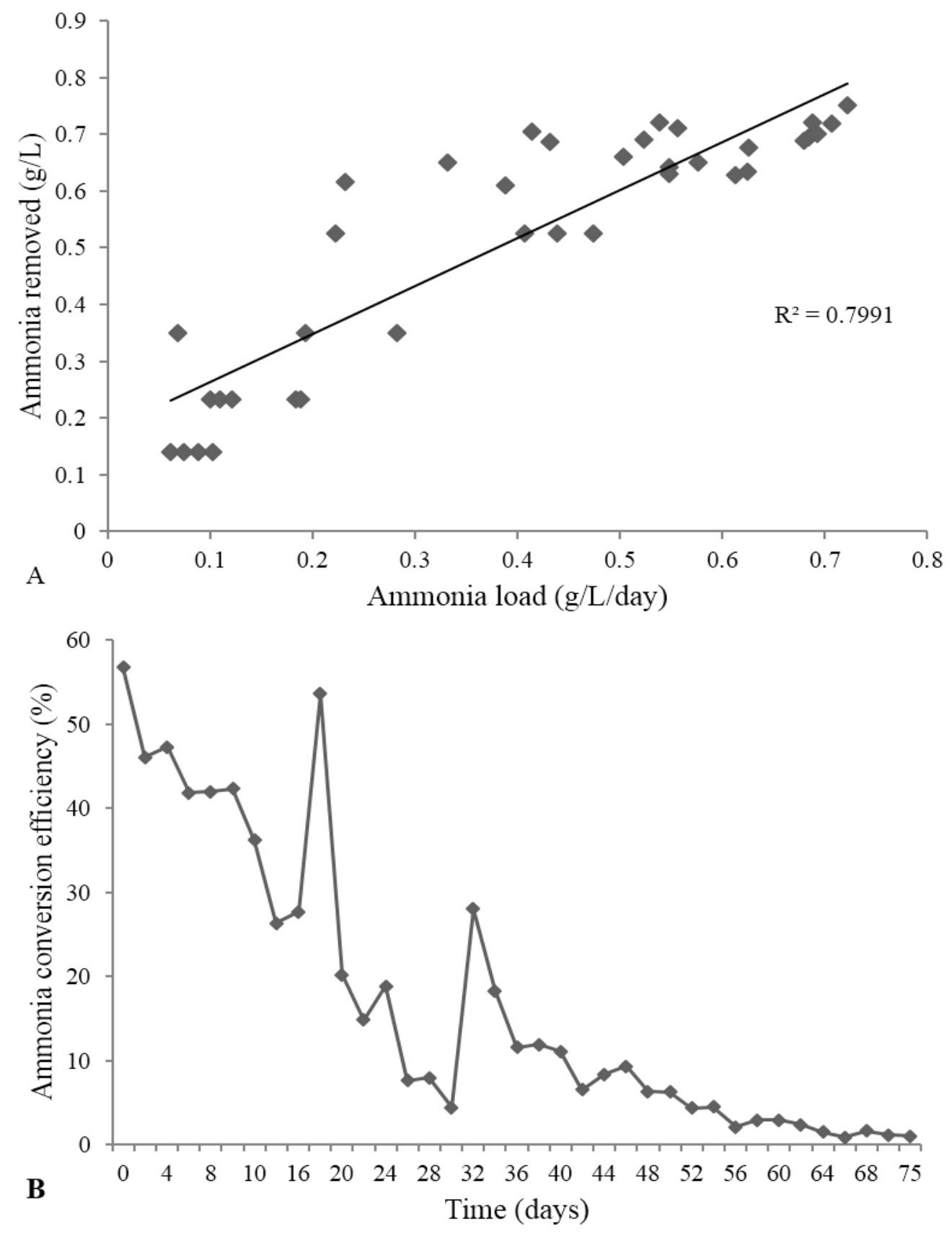

The growth of PF-AOB (specific growth rate constant 1.24 and doubling time of 0.56 ) was 3.214 times higher than that of PF-NOB (specific growth rate constant 0.384 and doubling time of 1.8 days). To get optimal removal of ammonia from the effluent, they 
were mixed such that $\mathrm{NOB} / \mathrm{AOB}$ ratio was 4 . This was in the range $1.72-5.87$ reported in wastewater treatment plants and aerobic granular sludge (Mari et al., 2012; Yao and Peng, 2017).

In municipal wastewater treatment plants, Harms et al., (2003) found that the number of NOB could be three times higher than AOB. However, there are reports which state that for balanced nitrifying system ratio of NOB: AOB should be 1:2- 1:2.7 (Mari et al., 2012).

\section{Ammonium removal from fertilizer industry effluent}

The seed consortia were then exploited for their ability to remediate high strength ammonia containing effluent from fertilizer industry in an open aerobic reactor. Oxygen and ammonia concentration play an important in co-culturing AOB and NOB.

In the presence of low oxygen concentrations, co-cultures of $\mathrm{AOB}$ and $\mathrm{NOB}$ is possible but levels of ammonia in the system should also be low (Sliekers et al., 2005). In the presence of high ammonia and low oxygen concentrations, NOB would be washed out of the reactors and ammonium would be converted to mainly nitrite, nitric oxide and nitrous oxide by Nitrosomonas sp. and other related bacteria (Sliekers et al., 2005; Keluskar et al., 2013). Ammonia levels were exceedingly high in the fertilizer effluent used in the present study, hence for simultaneous growth of $\mathrm{AOB}$ and NOB under identical conditions in a single reactor, oxygen concentration was also kept high to allow stable nitrification to occur in the system.

Results indicate that the developed aerobic suspended growth in the reactor system was highly efficient in removing ammonia up to 99\% and indigenous carbon from the effluent without accumulating nitrite or nitrate (Figure 3). It was therefore interesting to know the microorganisms present in the system as it would shed light on the metabolic activities going on in the reactor. Blast analysis of $16 \mathrm{~S}$ rRNA gene showed presence of AOB belonging to Nitrosomonas sp. which are mainly responsible for the reduction in the level of ammonia from the system. Presence of NOB, belonging to Nitrobacter sp., was also observed in the reactor.

They utilized nitrite present in the system and hence accumulation of nitrite was not observed (Figure 3B). Amongst NOB, Nitrobacter sp. are reported to have higher growth rate and affinity for nitrite and oxygen compared to other NOB like Nitrospira sp. (Schramm et al., 1991; Nogueira and Melo, 2006). Thus Nitrobacter sp. might have enriched from the paddy field soil sample and were consequently present in the system. Apart from AOB and NOB heterotrophic aerobic denitrifiers like Achromobacter sp., Sphingomonas sp., Pusillimonas sp., Mesorhizobium sp. and Alcaligenes sp. were also found to be present in the reactor (Patureau et al., 2000; Hayatsu et al., 2008; Srinivasan et al., 2010).

Achromobacter sp., is reported to denitrify at DO levels between 3 to $10 \mathrm{ppm}$ (Zhu et al., 2012). These denitrifiers are commonly found in wastewater treatment plants and can also carry out heterotrophic nitrification (Hayatsu et al., 2008). COD and DO play an important role in the denitrifying performance of reactor (Van Rijn et al., 2006). Heterotrophic denitrifiers utilize nitrite and nitrate produced by $\mathrm{AOB}$ and NOB as nitrogen and organic matter present in the effluent as carbon source. Therefore nitrite and nitrate accumulation was not observed and COD reduced from $46 \mathrm{mg} / \mathrm{L}$ to below detectable limits. Dependence of denitrifiers on the internal carbon source also restricts over growth of denitrifiers and helps in maintaining stable conditions in the reactor. High dissolved oxygen observed during the aeration and agitation period would favor nitrification whereas low DO observed during the off mode would favor aerobic denitrification, thus maintaining conditions for both the reactions to occur simultaneously in the same reactor. High HRT provided sufficient time for both 
nitrification and aerobic denitrification to occur effectively. Sludge settleability is an essential parameter in wastewater treatment plants (Tchobanoglous et al., 2003). Higher sludge retention can result in flocs of larger size and density which is extremely desirable for the SND process to proceed steadily (Zaizon, 2012). Settler tank attached to the aerobic reactor helped in retaining microorganisms in the present study. Compact sludge formed during the process (SVI was $22.4 \mathrm{ml} / \mathrm{g}$ ). Flocs formed in the reactor settled on the walls of the settler (Figure 1) and clear, odorless treated effluent was drained out of the reactor. Food to mass ratio in the present study was 0.45 , which was in the range (0.2 and 0.6) reported for maintaining a proper balance in the system (Tchobanoglous et al., 2003). As the amount of food is less than the microorganisms, the $\mathrm{C}$ and $\mathrm{N}$ present in the system would be immediately utilized.

Efficient simultaneous removal of nutrients was achieved with the concerted growth and activity $\mathrm{AOB}, \mathrm{NOB}$ and denitrifiers in the reactor without addition of an external carbon source. Aerobic SND processes thus have high potential to be effectively applied in the bioremediation of industrial effluent with extremely high ammonia concentrations. The only limiting factor in its application at large scale is the cost for aeration.

\section{Acknowledgements}

The author would like to thank Prof. Anjana Desai for her valuable guidance.

\section{References}

American Public Health Association, American Water Works Association, Water Environment Federation (APHAAWWA-WEF). 2005. Standards methods for the examination of water and wastewater. 21st edn. Washington, D.C.

Arjun, K. M. 2013. Indian Agriculture- Status, Importance and Role in Indian Economy. International Journal of Agricultural and
Food Science Technology. 4: 343-346.

Daigger, G. T., and Littleton, H. X. 2000. Characterization of simultaneous nutrient removal in staged, closed-loop bioreactors. Water Environment Research. 72: 330-339.

Daverey, A., Su, S. H., Huang, Y. T., and Lin J. G. 2012. Nitrogen removal from optoelectronic wastewater using the simultaneous partial nitrification, anaerobic ammonium oxidation and denitrification (SNAD) process in sequencing batch reactor. Bioresource Technology. 113: 225-231.

George, S., Chellapandian, M, Sivasankar, B., and Jayaraman, K. 1997. A new process for the treatment of fertilizer effluent using immobilized urease. Bioprocess Engineering. 16: 83-85.

Harms, G., Layton, A. C., Dionisi, H. M., Gregory, I. R., Garrett, V. M., Hawkins, S. A., Robinson, K. G., and Saylor, G. S. 2003. Real-Time PCR quantification of nitrifying bacteria in a municipal wastewater treatment plant. Environmental Science and Technology. 37: 343-351.

Hayatsu, M., Tago, K., and Saito, M. 2008. Various players in the nitrogen cycle: Diversity and functions of the microorganisms involved in nitrification and denitrification. Soil Science and Plant Nutrition. 54: 33-45.

Hyman, M. R., and Arp, D. J. 1992. $14 \mathrm{C}_{2} \mathrm{H}_{2}$ and $14 \mathrm{CO}_{2}$-labeling studies of the de novo synthesis of polypeptides by Nitrosomonas europaea during recovery from acetylene and light inactivation of ammonia monooxygenase. The Journal of Biological Chemistry. 267: 1534-1545.

Keluskar, R., Nerurkar, A., and Desai, A. 2013. Development of a simultaneous partial nitrification, anaerobic ammonia oxidation and denitrification (SNAD) bench scale process for removal of ammonia from effluent of a fertilizer industry. Bioresource Technology. 130: 390-397.

Mari, K. H., Joao, P. B., Robbert, K., Dimitry, 
Y. S., and Mark, C. M. 2012. Unravelling the reasons for disproportion in the ratio of $\mathrm{AOB}$ and $\mathrm{NOB}$ in aerobic granular sludge. Applied Microbiology and Biotechnology. 94: 1657-1666.

Nogueira, R., and Melo, L. F. 2006. Competition between Nitrospira spp. and Nitrobacter spp. in nitrite-oxidizing bioreactors. Biotechnology and Bioengineering. 95: 169-175.

Obire, O., A. Ogan, R. N. Okigbo. 2008. Impact of fertilizer plant effluent on water quality. International Journal of Environment Science and Techechnology. 5: 107-118.

Patureau, D., Zumstein, E., Delgenes, J. P., and Moletta, R. 2000. Aerobic denitrifiers isolated from diverse natural and managed ecosystems. Microbial Ecology. 39: $145-152$.

Schmidt, T. M., Delong, T. E. F., and Pace, N. R. 1991. Analysis of a Marine Picoplankton Community by $16 \mathrm{~S}$ rRNA Gene Cloning and Sequencing. Journal of Bacteriology. 173: 4371-4378.

Schramm, A, de Beer, D., Van Den Heuvel, J. C., Ottengraf, S., and Amann, R. 1999. Microscale Distribution of Populations and Activities of Nitrosospira and Nitrospira spp. along a Macroscale Gradient in a Nitrifying Bioreactor: Quantification by In Situ Hybridization and the Use of Microsensors. Applied and Environmental Microbiology 65: 36903696.

Siripong S., and Rittmann, B. E. 2007. Diversity study of nitrifying bacteria in full-scale municipal wastewater treatment plants. Water Research. 41: 1110-1120.

Sliekers, A. O., Haaijer, S. C. M., Stafsnes, M. H., Kuenen, J. G., and Jetten, M. S. M. 2005. Competition and coexistence of aerobic ammonium and nitrite-oxidizing bacteria at low oxygen concentrations. Applied Microbiology and Biotechnology. 68: 808-817.

Srinivasan, S., Kim, M. K., Sathiyaraj, G., Kim, Y.-J., and Yang, D.-C. 2010. Pusillimonas ginsengisoli sp. nov., isolated from soil of a ginseng field. International Journal of Systematic and Evolutionary Microbiology. 60: 17831787.

Strous, M., Kuenen, J. G., and Jetten, M. S. M. 1999. Key physiology of anaerobic ammonium oxidation. Applied and Environmental Microbiology. 65: 32483250.

Tchobanoglous, G., Burton, F., Stensel, H. 2003. Wastewater Engineering, Treatment and Reuse. Metcalf and Eddy, Inc., McGraw-Hill Companies, New York, 661-883.

Van Rijn, J., Tal, T., and Schreier, H. J. 2006. Denitrification in recirculating systems: theory and applications. Aquatic Engineering. 34: 364-376.

Yao, Q., and Peng, D-C. 2017. Nitrite oxidizing bacteria (NOB) dominating in nitrifying community in full-scale biological nutrient removal wastewater treatment plants. AMB Express, 7:25.

Zajzon, G. 2012. Simultaneous nitrification and denitrification process in the municipal wastewater treatment. Conference on Junior Research and Civil Engineering. 282-288.

Zhu, L., Ding, W., Feng, L., Kong, Y., Xu J., and $\mathrm{Xu}, \mathrm{X}$. 2012. Isolation of aerobic denitrifiers and characterization for their potential application in the bioremediation of oligotrophic ecosystem. Bioresource Technology. 108: 1-7.

\section{How to cite this article:}

Radhika Priyadarshan Keluskar. 2017. Bioremediation of High Strength Ammonia Laden Fertilizer Industry Effluent With Extremely Low C: N Ratio Using Simultaneous Aerobic Nitrification and Denitrification. Int.J.Curr.Microbiol.App.Sci. 6(12): 3029-3039.

doi: https://doi.org/10.20546/ijcmas.2017.612.354 